\title{
Determining the influence of the social versus physical context on environmentally responsible behaviour among cycling spectators
}

\author{
E.A.du Preez ${ }^{1}$ \& E.T. Heath \\ Division Tourism Management, Department of Marketing Management, University of Pretoria, \\ Pretoria, South Africa
}

The paper explores the relationships between three factors and environmentally responsible behavioural intentions among cycling spectators: place attachment, subculture identification and subjective norms. Two categories of behavioural intentions are presented namely situational (while spectating) and future (before attending similar events). ANCOVA is used to test the relationships in a sample of 619 spectators from both road race and mountain bike events. The paper supports previous research highlighting the importance of the social dimension of sport spectating and the link to social norms that drive environmental behaviour. It also adds to existing research on place attachment as a precursor to environmentally responsible behaviour with reference to sport spectating.

Keywords: environmentally responsible behaviour, cycling spectators, place attachment, subculture identification, subjective norms

\section{Introduction}

Many outdoor sporting codes depend on the natural environment in which they are performed and the quality thereof directly affects participants' experiences (Hinch \& Higham, 2011). An increasing number of studies explores the role of the sports organisation, management and policies to promote environmentally responsible behaviour among consumers (for example Casper \& Pfahl, 2012; Casper, Pfahl \& McCullough, 2014; Inoue, Kent \& Smart, 2012; Kellison \& Kim, 2014; Pfahl, 2010); an important endeavour as the behaviour of consumers is essential to the success and effective execution of environmental management initiatives (Sheth, Sethia \& Srinivas,

\footnotetext{
${ }^{1}$ Corresponding author: EA du Preez (Elizabeth.dupreez@up.ac.za; +2782 543 2316)
} 
2011; Stanford, 2008). Still not enough is known about the environmentally oriented behaviour of spectators as one group of these consumers (Nguyen, Iacono \& Stratmann, 2011); despite recent advances in the field of environmental sustainability for sport events (discussed in Sotiriadou \& Hill, 2015).

Environmental behaviour is strongly influenced by individual differences in people (Dolnicar \& Grün, 2009; Mehmetoglu, 2010; Miao \& Wei, 2013) while also taking place within a social context (Günther, 2009:359; Winkel, Seagert \& Evans, 2009). Behaviour takes place within a specific 'situation' known as the behavioural setting - a point in time and place (Belk, 1975; Pearce, 2005) and includes the physical as well as the social surroundings (Belk, 1975). To study environmentally responsible behaviour of individuals in a sport spectating context, it is thus important to define the relevant situational characteristics and to explore behaviour against the backdrop of a particular spatial setting (Günther, 2009). King, Kahle and Close (2011) similarly argue that to explore consumer behaviour in sport, aspects unique to sport consumption as the social context should be considered. Environmental behaviour therefor has to be explored within the behavioural setting of the sport type under investigation to understand the influence on behaviour of individuals.

Cycling tourism is a growing niche market (Ritchie, Tkaczynski \& Faulks, 2010) and cycling routes and cycle tourism developments are increasingly being integrated into sustainable development and transport policies (Pucher, Buehler \& Seinen, 2011; Pucher, Garrard \& Greaves 2011; Ritchie et al., 2010). The growing interest in cycling has also been witnessed in South Africa as country where the research was conducted; surpassing golf in popularity among corporates and with a proliferation of cycling events attracting international attention (Barry, 2014; Du Toit, 2013; Hardisty, 2014). The sport has become synonymous with environmental 
responsibility, healthy living and carbon free transport (Aldred, 2010; Cupples \& Ridley, 2008) with bicycle tourism even being named an environmentally sustainable niche market (Lamont, 2009). Yet not a lot is known about the environmental behaviour of both active and passive participants of cycling events.

Cycling races attract large crowds with spectators spread along the route of the race. As races mostly occur outdoors in public spaces there is arguably less control over the environmental behaviour of the spectators than in the case of gated events where appropriate facilities are provided in a confined space. The active participants (cyclists) may be guided by sporting codes of conduct and unofficial norms that develop among them (after Fink \& Smith, 2012), while this may not be the case among spectators and even more so in the case of environmental behaviour. Spectators have a big environmental impact, travelling to the event and spending time in the event's surrounding environment. The ecological footprint of spectators to the opening of the Tour de France has for example been equated to 57,990 global hectares or 143 times the area of London's Olympic Park, mainly due to transport, accommodation and consumables (Collins, Roberts \& Munday, 2012). Where the cyclists may be focused on the sporting activity and be less inclined to engage with the wider environmental setting, the opposite may be true of spectators who often interpret the space as a leisure setting (Snelgrove \& Wood, 2010). Furthermore, spectators at outdoor events do not play the same significant role in the income model of event organisers as is the case with stadium spectators that bring income through ticket sales, refreshments and merchandise purchases (Szymanski, 2003). This may have added to the current situation where research is dominated by a focus on participants in the case of outdoor events.

Using cycling with its two distinct forms (Kruger \& Saayman, 2014) as sport type where the surrounding environment forms an essential part of the experience 
(Kulczycki \& Halpenny, 2014), this paper explores the relative importance of the social versus the physical context to encourage environmental behaviour in an outdoor spectator sport setting.

\section{Literature overview}

The literature overview starts off with a definition of environmental behavioural, followed by an exposition of three factors from social psychology theory that could have relevance as influencers of behaviour within the setting of cycling spectators.

\section{Desirable environmental behaviour}

\section{Definition and measurement of environmentally responsible behaviour}

Environmentally responsible behaviour is defined as “...either repeated or occasional concrete behavioural choices made in everyday environments. They concern specific natural and common resources of these daily environments such as choices of use/maintenance of specific resources, including water, air, land, sources of energy ... and other more or less recyclable materials ... as well as of life forms present in the environment." (Bonnes \& Bonaiuto, 2002:35). The aim of understanding environmental behaviour of individuals should be to prepare, guide and establish behavioural choices that are more or less pro-environmental (Bonnes \& Bonaiuto, 2002).

The study of individuals' behaviour toward the environment falls within the interdisciplinary field of environmental psychology where theory from among others social psychology is used to explain behaviour. Environmentally responsible behaviour can be viewed from two perspectives, with each perspective being represented by specific theoretical models (Bamberg \& Möser, 2007; Klöckner \& Blöbaum, 2011). Firstly, it can be seen as a matter of self-interest, where the focus is on strategies to 
minimise one's own health risks. Researchers following this view rely on rational choice models such as Ajzen and Fishbein's (1980) Theory of Reasoned Action and Ajzen's (1991) Theory of Planned Behaviour where behaviour is driven by behavioural, normative and control beliefs and mediated by behavioural attitude. Secondly, it can be seen as something that is pro-socially motivated with the focus on concern for other people, future generations, or biospheric systems. Researchers following this view refer to models such as Schwartz's (1977) Norm-Activation-Model or Stern's (2000) Values-Beliefs-Norms model as theoretical frameworks. Still, it is never just one of these, but rather a mixture of both as attested to in the multitude of models depicting the factors that drive behaviour (for example Bamberg \& Möser, 2007; Klöckner \& Blöbaum, 2011; Milfont, Duckitt \& Wagner, 2010; Steg, Bolderdijk, Keizer \& Perlaviciute, 2014). Kollmuss and Agyeman (2002) argued that the question of what shapes environmentally responsible behaviour is such a complex one that it cannot be visualised in one single framework or diagram.

The readiness to perform certain behaviour is known as behavioural intention (Ajzen, 1991). "This readiness to act can be operationalised by asking whether people intend to engage in the behaviour, expect to engage in the behaviour, are planning to engage in the behaviour, will try to engage in the behaviour, and indeed, whether they are willing to engage in the behaviour." These various expressions of behavioural readiness reflect the same underlying construct - intention (Ajzen, 2011). The stronger a person's intention to engage in a behaviour, the more likely he or she is to perform it (Ajzen, 1991). The majority of behavioural studies focus on behavioural intention as opposed to actual behaviour (Nigbur, Lyons \& Uzzell, 2010), with various models using intention as a strong predictor for actual behaviour (such as Bamberg \& Möser, 2007; Milfont et al.,2010; Montaño \& Kasprzyk, 2008; Klöckner \& Blöbaum, 2011). When a 
series of behaviours have to be reported on, each situation has to be 'imagined' by the individual and then judged according to whether, given the opportunity, it will be done or not. Still, a prominent feature of behaviour research is the occurrence of the attitudebehaviour gap (Blake, 1999, Kollmus \& Agyeman, 2002) and very few studies measure behavioural intention as well as resultant actual behaviour.

Taking cognisance of the multitude of factors that could possibly be influencers of environmental behaviour, three constructs have been identified that could be relevant to represent the social and physical dimensions in the context of sport spectating. Before presenting these factors, a description of the behavioural 'setting' of this research is provided.

\section{Responsible behaviour within the sports event context}

The essential behaviour that should be measured among outdoor sport even spectators can be linked back to the environmental management practices employed by the event organiser. Yang, Yang and Peng (2011) identify the environmental management system as all efforts to minimise the negative environmental impacts of an organisation's processes and product throughout the entire production lifecycle. Pertinent activities include those related to transport, eco-design, water management, waste management, recycling, re-use, sporting goods, energy management, $\mathrm{CO} 2$ offset, public awareness, and policy (taken from GSA, 2006; Laing \& Frost, 2010; Schmidt, 2006). Other examples include signposts, banning traffic and movement in certain areas, route marking, setting up obstacles, restricting activities during certain periods of time (Jagemann, 2003). Having appropriate facilities available to spectators are extremely important to encourage desired behaviour. For example, while $90 \%$ of spectators to the London opening of the Tour de France indicated being regular 
recyclers at home, $30 \%$ indicated that they did not recycle while spectating due to a lack of accessible recycling facilities (Collins et al., 2012).

In the context of managing sports event spectator behaviour, there can arguably be two broader categories. Firstly, preparing attendees for and guiding them to act responsibly once they step into the behavioural setting (at an event). Secondly, contributing to a sense of commitment toward the environment that will encourage the desired behaviour in future. These two 'stages' are visible in Sahler's (2007) layout of the five phases of an event's production process. Environmentally responsible behaviour will play a part of the sports consumption process to a greater or lesser extent during the different phases and it is appropriate to undertake an investigation of not only the behavioural intention while in the setting, but also future intended behaviour. Funk (2008) similarly explains that behavioural outcomes can include purchase behaviour (or in this case the decision to attend the event), post-decision activities of the purchase behaviour (transport, activities undertaken while spectating), and post-experience behaviour (activities after attending the event). Not a lot is known about the effects that a travel experience may or may not have on the individual. Even though environmental learning and behavioural change as a result of experiences have been explored in both tourism (see Kachel \& Jennings, 2010; Lee \& Moscardo, 2005; Moscardo, 2009) and sports (see Brymer, Downey \& Gray, 2009; Ray, 2009), there is said to be no strong evidence of significant or substantial changes to the individual tourist/traveller/ participant's knowledge (Moscardo, 2009; Wu, Huang, Liu \& Law, 2013).

To effectively address sustainability challenges tourists have to be provided with guidelines beyond the mere 'reduce, re-use, recycle' approach through the communication of specific principles (Middleton \& Hawkins, 1998 in Pearce, 2011). Firstly, recognition of the impacts of one's own actions; secondly, refusal to make 
unethical purchases; thirdly, replacing of high impact with lower impact experiences; fourthly, retraining oneself in order to be less dependent on high impact activities; fifthly, rewarding oneself by making use of incentives that promote sustainable; and lastly, re-education to change one's personal behaviour based on tourists experiences. Once tourists have undergone a personal change in thinking on the issue, the sustainability of an event may become a part in the decision to attend these types of events in future (Laing \& Frost, 2010) or even refraining from travel at all for the sake of the environment (Puczkó \& Smith, 2012). However, most tourists (as consumers) are "superficial environmentalists" who are 'concerned' but very reluctant to undertake any corrective actions that inconvenience them (Weaver, 2012).

In summary, environmentally responsible behaviour of sport event spectators can be divided into two aspects, namely the Situational Intention and Future Intention, comprising of the aspects discussed (summarised in Table 1). Situational intention will be the readiness to perform behaviour in a more or less pro-environmental direction while spectating; future intention will be the readiness to perform pro-environmental behaviour related to, but away from the event and before future attendance.

After establishing the relevant aspects of the behavioural setting under investigation, the next three sections present three context-specific factors that could influence the behaviour of individuals, namely place attachment, subculture identification and subjective norms. 
Table 1: Environmentally responsible behaviour to be measured

\begin{tabular}{|c|c|c|c|}
\hline $\begin{array}{l}\text { Environmental } \\
\text { management } \\
\text { component }\end{array}$ & Possible spectator behaviour & 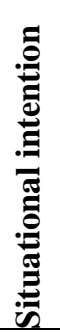 & 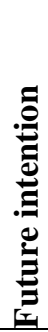 \\
\hline \multirow{3}{*}{ Water management } & Closing taps & $\checkmark$ & \\
\hline & Refilling water bottles with tap water & $\checkmark$ & \\
\hline & Not polluting natural water sources & $\checkmark$ & \\
\hline \multirow{5}{*}{ Waste management } & Making use of the ablution facilities provided & $\checkmark$ & \\
\hline & Throwing rubbish in the bins provided & $\checkmark$ & \\
\hline & Participating in recycling activities & $\checkmark$ & \\
\hline & Picking up litter (during or after the race) & $\checkmark$ & \\
\hline & $\begin{array}{l}\text { Making a financial contribution toward an event's clean-up } \\
\text { and recycling initiatives }\end{array}$ & & $\checkmark$ \\
\hline Energy management & $\begin{array}{l}\text { Making use of public transport/car-pooling to reduce the } \\
\text { carbon footprint of an event }\end{array}$ & & $\checkmark$ \\
\hline \multirow{3}{*}{$\begin{array}{l}\text { Protection of } \\
\text { biodiversity }\end{array}$} & Parking cars in designated parking areas & $\checkmark$ & \\
\hline & Staying within the designated viewing areas & $\checkmark$ & \\
\hline & Respecting plants and animals & $\checkmark$ & \\
\hline $\begin{array}{l}\text { Aesthetics and noise } \\
\text { pollution }\end{array}$ & Refraining from making noise & $\checkmark$ & \\
\hline \multirow{2}{*}{$\begin{array}{l}\text { Information } \\
\text { communication } \\
\text { (encouragement) }\end{array}$} & Reading the information signs to guide behaviour & $\checkmark$ & \\
\hline & $\begin{array}{l}\text { Reading the event's environmental rules and regulations } \\
\text { before actual attendance }\end{array}$ & & $\checkmark$ \\
\hline $\begin{array}{l}\text { Management of non- } \\
\text { compliance }\end{array}$ & Reporting inappropriate behaviour of other spectators & $\checkmark$ & \\
\hline \multirow{2}{*}{$\begin{array}{l}\text { Marketing } \\
\text { communication }\end{array}$} & $\begin{array}{l}\text { Following an event's environmental initiatives in the media } \\
\text { before deciding to return }\end{array}$ & & $\checkmark$ \\
\hline & $\begin{array}{l}\text { Supporting a sustainable event's sponsors because of the } \\
\text { association with responsible practices }\end{array}$ & & $\checkmark$ \\
\hline \multirow{3}{*}{ Other } & $\begin{array}{l}\text { Willingness to make a financial contribution toward the } \\
\text { event's environmental initiatives }\end{array}$ & & $\checkmark$ \\
\hline & $\begin{array}{l}\text { Willingness to watch the race on television or over the } \\
\text { internet in order to reduce the environmental impact of the } \\
\text { event }\end{array}$ & & $\checkmark$ \\
\hline & $\begin{array}{l}\text { Sign a petition against the event if it becomes known that } \\
\text { the event has a negative impact on the environment where it } \\
\text { takes place }\end{array}$ & & $\checkmark$ \\
\hline
\end{tabular}

Source: taken from Greening the WSSD (2003), GSA (2006), Jagemann (2003), Kang and Stotlar (2011), Laing and Frost (2010), Pearce (2005), Sahler (2007), Schmidt (2006), Responsible Traveller Magazine (2014)

\section{Place attachment}

Place attachment can be defined as any positive or negative relationship that a person

has with the location of the sports event or the specific sports event, creating an 
emotional bond with that place or event (adapted from Kyle, Graefe, Manning \& Bacon, 2003). It is concerned with the specific meaning attached to a space (physical and geometric) (Hinch \& Higham, 2011; Weed \& Bull, 2004).

Place attachment may be an important factor underlying or providing impetus to a spectator's intention to behave responsibly during an event (McCullough \& Kellison, 2016) and this attachment is regarded as a vital consideration in natural resource management strategies (Lee, 2011; López-Mosquera \& Sánchez, 2012; Ramkissoon, Smith \& Weiler., 2013; Snider, Hill, Luo, Buerger \& Herstine., 2011). Different levels of place attachment will lead to different levels of concern about the state of the natural resources in a specific setting (Kyle et al. 2004; Snider et al., 2011) and a heightened sense of attachment could lead to greater propensity to display responsible behaviour in such a setting (Halpenny, 2010; Ramkissoon et al., 2013). In some instances place attachment may lead to a greater willingness to sacrifice resources toward protection of the place (Kyle et al., 2003; López-Mosquera \& Sánchez, 2012). Once individuals feel a sense of ownership toward a place where they participate in recreational activities, they are inclined to display responsible behaviour (Trendafilova, 2011). This may depend on the number of visitations to a place (Snider et al., 2011), the perceived benefits received through visitation (López-Mosquera \& Sánchez, 2012) and the specific meaning attached to a place by the visitor (Wynveen, Kyle \& Sutton, 2012). Increased knowledge about a place through information provision (Halpenny, 2010) or through regular use (Thompson, Davidson \& Hutson, 2008) also increases the likelihood that an individual will display responsible behaviour in order to protect the place. Similar to the findings of Laing and Frost (2010) in corporate events, there may be instances where a stronger sense of attachment may be developed toward a sports event or activity if it is associated with socially responsible practices (Filo, Funk \& O’Brien, 2008). 
Sport event spectators will have different drivers of attachment than active participants. Where participants may for example be attached to an event due to its level of organisation and ability to prove their skills (Kruger \& Saayman, 2014), spectators may have a bond based on the socialisation opportunities, entertainment value or the nature of the event setting. Some spectators may feel attachment to the wider destination or place, while others focus on the event and its participants. These varied focuses will arguably influence their orientation toward the environment in which the event takes place; affecting the extent of their concern with and intention to act responsibly in the setting (McCullough \& Kellison, 2016).

\section{Subculture identification and subjective norms}

The desire to be part of the subculture of the sport at an event remains one of the key motives driving attendance (Green \& Chalip, 1998; Snelgrove, Taks, Chalip \& Green, 2008). Understanding the subculture of a sport is important to drive consumer behaviour in the desired direction (Green, 2001) and event organisers are increasingly engaging with "sport fan consumption communities" to do so (Hedlund, 2012).

Subculture identification is a process whereby the beliefs and values held by a particular sports consumption community are adopted and internalised by individual consumers. Individuals use their affiliations with sports to express aspects of their selfconcept to others (Hirt \& Clarkson, 2011; Scammon, Fuller, Karniouchina \& Masters, 2011; Shipway \& Kirkup, 2011). They may see themselves as a 'typical' supporter or fan and they may also be known as such. Individuals with a strong sense of subculture identification will possibly be more inclined to change behaviour in the spectator setting in order to feel an increased sense of belonging and to make a connection with peers.

Some outdoor sports cultures have become synonymous with either being unsustainable or 'green' (Mansfield \& Wheaton, 2011) though very little research has 
been done on this topic. The so-called 'lifestyle sports' also referred to as "free sports", "alternative sports" and "fringe sports" have been associated with environmentally conscious participants and nature-friendly practices (Brymer \& Gray, 2010; Salome, van Bottenburg \& van den Heuvel, 2013); spurred on by the fact that these sports codes are highly dependent on the natural resources where they take place. The surfer culture has effectively been harnessed to address water pollution issues (Wheaton, 2007). Similarly, disc golf players have been encouraged to display responsible behaviour through the culture among golfers at a park (Trendafilova, 2011). In a different context, a resident subculture built around affiliation with a local football club has also been used in a campaign to promote pro-environmental behaviour (Baldwin, 2010).

It is argued that, the more a spectator associates with other spectators of the specific sport, the more they are inclined to follow the group's behaviour in terms of specific activities (in this case environmentally responsible behaviour) (McCullough \& Kellison, 2016). The distinct subculture of cycling participants as consumers have been researched (discussed in Kruger \& Saayman, 2014), but not a lot is known about the existence of subcultures among the spectators of these events.

Group affiliation is closely linked to the concept of social norms (Andorfer \& Liebe, 2013, Hedlund, 2012). Social norms are defined as rules and standards that are understood by members of a group, and that guide and/or constrain social behaviour without the force of laws" (Cialdini \& Trost, 1998:152). Social norms influence personal norms, or an individual sense of obligation to engage in a particular action (Cameron, 2002). It is one of the main predictor variables in the widely applied Theory of Planned Behaviour (TPB) and has been directly linked to behavioural intention (Bamberg \& Möser, 2007; Klöckner \& Blöbaum, 2011; Milfont et al., 2010; Montaño \& Kasprzyk, 2008). It would be appropriate to strengthen the predictive power of 
subjective norms through the addition of social aspects of behaviour such as a sport subculture (Nigbur et al., 2010).

Norms are categorised by various terms including moral norms, personal norms, social norms and ecological norms, depending on the context in which they are being applied. Subjective norms refers to norms as a social factor regarding "the perceived social pressure to perform or not to perform the behaviour." (Ajzen, 1991:188). They are the "rules and standards that are understood by members of a group, and that guide and/or constrain social behaviour without the force of laws." (Cialdini \& Trost, 1998:152). Social norms influence personal norms, or an individual sense of obligation to engage in a particular action (Cameron, 2002) in order to obtain favourable results (Iconaru, 2012; Steg et al., 2014) such as approval by important referent individuals or groups (Ajzen, 1991). Several studies have indicated this approval to be a strong predictor of a person's intention to perform a specific behaviour (Iconaru, 2012).

Social norms are followed conditionally upon the satisfaction of two expectations, namely normative expectations (what one thinks others expect from you) and empirical expectations (what one has observed or knows about the behaviour of others in similar situations) (Bicchieri, 2006). For social norms to exist, there has to be a sufficient number of people that know that the norm exists and that share the same expectations (Bicchieri, 2006; Elster, 1999). Furthermore, there should be a sufficient number of people that have a conditional preference to comply with the norm (Bicchieri, 2006). Another feature of social norms is that they are enforced by sanction mechanisms directed at violators, where the fear of punishment (in the form of being seen by others doing something inappropriate) can motivate people to comply with the norm. Therefore the activation of social norms depends strongly on the fact that the individual is "being observed by others." (Elster, 1999:196). 
Behaviour often takes place in a social context, such as this study's context of sport spectating. It is therefore likely that the behaviour of others will influence the behavioural decision of individuals (Biel \& Thogersen, 2007). The extent of this influence will also vary according to the behavioural situation (Fishbein \& Ajzen, 1975, in Iconaru, 2012). For example, a study by Goldstein, Cialdini and Griskevicius (2008) found that hotel guests were more encouraged to participate in an environmental conservation programme through signage that used descriptive norms (other guests are performing the behaviour), than signage that focused on environmental protection. Furthermore, normative appeals that described the behaviour of other individuals in the same setting (the same floor/room) proved to be even more effective. Similarly, McCullough and Cunningham (2011) and McCullough (2013) found that seeing other spectators partaking in recycling and seeing famous sport stars participating in recycling, and hearing them make announcements to encourage recycling, had different effects on spectator recycling. They also found subjective norms (other families at the tournament and significant others) as one of the greatest influences on spectators' recycling intentions.

It is argued that the discussed constructs are important dimensions of sport spectatorship and that all three contain aspects that may link to environmental behaviour. Items derived from the literature to construct the factors for statistical measurement are indicated in Table 2. 
Table 2: Measurement scales for place attachment, subculture identification and subjective norms

\begin{tabular}{|c|}
\hline Place attachment \\
\hline $\begin{array}{l}\text { - I am very attached to visiting this place specifically. } \\
\text { - I have a special connection to attending this cycling race. } \\
\text { - }\end{array}$ \\
\hline Subculture identification \\
\hline $\begin{array}{l}\text { - My friends and family know me as a cycling supporter/fan. } \\
\text { - The sport of cycling describes me as a person. } \\
\text { - I strongly relate with other spectators and feel 'at home'. }\end{array}$ \\
\hline Subjective norms \\
\hline $\begin{array}{l}\text { - Seeing other spectators being environmentally responsible. } \\
\text { - } \quad \text { Being looked down upon if I am not environmentally responsible. } \\
\text { - } \quad \text { Bnowing that other spectators expect me to behave in an environmentally responsible manner. } \\
\text { - } \quad \text { Knowing that no one else is being environmentally responsible } \\
\text { - Seeing the cyclists being environmentally responsible. }\end{array}$ \\
\hline
\end{tabular}

The question is posed whether they have equally important interactions with a spectator's intentions to display environmentally responsible behaviour within the situational setting, but also in terms of future behaviour. Furthermore, whether these variables are the same across different spectator groupings based on the type of events (road versus mountain bike). An article by McCullough and Kellison (2016) developed a conceptual model to test the influence of sense of place (which incorporates place attachment) and fan identification on environmental behaviour. However, the model proposes fan identification as a variable that moderates the relationship between sense of place and behaviour and only looks at behaviour while attending a sport event.

\section{Methodology}

\section{Sample}

Self-completion surveys were completed at seven different cycling events (both mountain bike and road races) in South Africa. Non-probability sampling in the form of convenience sampling was used to solicit participants (spectators) along the various routes. Because the quality of the research would be affected by using convenience 
sampling (Saunders, Lewis \& Thornhill, 2007), the researchers employed heterogeneous or maximum variation sampling to include different (heterogeneous) individuals. A final sample of 619 spectators was included.

\section{Measurement instrument}

A self-completion questionnaire was chosen as self-administered surveys improve anonymity (Keyton, 2011). Situational and future intention were measured at the hand of 4-point Likert-type scales, ranging from 1 = 'Definitely not', 2 = 'Unlikely', 3 = 'Maybe' to 4 = 'Definitely'. The question for situational intention was stated as "Activities that you undertake as a spectator at this event". With the scale using 'unlikely' and 'maybe' as descriptors, the scale measured intention and not actual behaviour as it asked people whether they intended, expected or planned to engage in the behaviour (Ajzen, 2011). Asking people whether they had actually performed the behaviour only ('definitely not' or 'definitely') would most likely have resulted in "over-reporting of admirable attitudes and behaviors" known as social desirability bias (Krosnick, 1999:545). True measurement of behaviour would arguably require a qualitative methodology such as participant observation or other forms of 'evidence' for the actual behaviour. The decision to test intentions could therefore be considered a limitation of the study. Place attachment and subculture identification were also measured on a 4-point scale, ranging from $1=$ 'Strongly disagree' to $4=$ 'Strongly agree'. The researchers opted not to include a middle value ('not sure' / 'don't know') as people often perceive the middle of the scale as the 'normal' or 'typical' value and tend to place themselves near that point, regardless of the label given (Krosnick, 1999:544). Subjective norms was measured on a 3-point scale where $1=$ 'not at all encouraging', 2 = 'to some extent encouraging', 3 = 'very encouraging'. 


\section{Data analysis}

Initial descriptive statistics were used to describe the sample and data. Cronbach's Alpha coefficients were used to test internal reliability of the scales. T-tests were firstly used to determine the differences between the two spectator groups for all of the scale items as well as the scale composite scores. Thereafter the relationships between the three independent variables (place attachment, subculture identification and subjective norms) and two grouping categories (mountain bike versus road cycling) were tested to see which of these variables had the largest effect size with the two outcome variables (situation and future intention). Analyses of variance techniques such as ANOVA and MANOVA are well-established and frequently used technique in tourism studies (Tang, 2014). However, it only allows for testing the relationship between one independent continuous variable and categorical variables. A procedure known as univariate analysis of covariance (ANCOVA) effectively combines ANOVA with regression (interaction between more than one continuous independent variable) into a linear model (Field, 2013). It allowed the researchers to simultaneously test the effect of the setting (mountain bike versus road race) and the three factors on behavioural intentions by systematically including each variable through step-wise regression. This technique has been used in research with a similar theme, including to test the differences in environmental attitudes of nature-based tourists based on their motivations (Luo \& Deng, 2008); the differences in pro-environmental product choices between different consumers based on environmental concern (Cornelissen, Pandaleare, Warlop \& Dewitte, 2008); and differences in behaviour based on environmental attitudes and knowledge between different cultural groups (Laroche, Tomiuk, Bergeron \& BarbaroForleo, 2002). 


\section{Description of the sample}

The sample consisted of 446 (72\%) road race spectators and 173 (28\%) mountain bike spectators. The profile of the different events is indicated in Table 3.

Table 3: Profile of events

\begin{tabular}{|l|l|c|c|c|l|}
\hline \multicolumn{1}{|c|}{ Province } & \multicolumn{1}{|c|}{ Type } & $\begin{array}{c}\text { Sample } \\
\text { size }\end{array}$ & $\begin{array}{c}\text { Years* } \\
\text { running }\end{array}$ & $\begin{array}{c}\text { Nr of } \\
\text { cyclists }\end{array}$ & \multicolumn{1}{|c|}{ Landscape } \\
\hline $\begin{array}{l}\text { Gauteng } \\
\text { (inland) }\end{array}$ & Road & 191 & 18 & 30000 & $\begin{array}{l}\text { Urban spaces (from inner city to suburbs } \\
\text { and peripheral areas of large city) }\end{array}$ \\
\hline $\begin{array}{l}\text { Gauteng } \\
\text { (inland) }\end{array}$ & Road & 32 & 17 & 3000 & Peripheral areas of large city \\
\hline $\begin{array}{l}\text { Eastern Cape } \\
\text { (coastal) }\end{array}$ & Road & 78 & 30 & 4000 & $\begin{array}{l}\text { Urban spaces (from inner city to suburbs } \\
\text { and peripheral areas of large city) }\end{array}$ \\
\hline $\begin{array}{l}\text { Eastern Cape } \\
\text { (coastal) }\end{array}$ & $\begin{array}{l}\text { Mountain } \\
\text { Bike }\end{array}$ & 45 & 30 & 150 & Farmlands and mountain \\
\hline $\begin{array}{l}\text { Western Cape } \\
\text { (coastal) }\end{array}$ & Road & 145 & 37 & 35000 & $\begin{array}{l}\text { Urban spaces (from inner city to } \\
\text { suburbs) }\end{array}$ \\
\hline $\begin{array}{l}\text { Western Cape } \\
\text { (coastal) }\end{array}$ & $\begin{array}{l}\text { Mountain } \\
\text { Bike }\end{array}$ & 41 & 14 & 3000 & $\begin{array}{l}\text { Farmlands and mountain } \\
\text { (conservancy area) }\end{array}$ \\
\hline $\begin{array}{l}\text { Western Cape } \\
\text { (coastal) }\end{array}$ & $\begin{array}{l}\text { Mountain } \\
\text { Bike }\end{array}$ & 87 & 12 & 1200 & Farmlands and mountain \\
\hline
\end{tabular}

*In 2015

The majority participants was female (68\%), held a tertiary qualification (70\%) with an average age of 37 (minimum age of 18). Spectators originated primarily from neighbouring towns/cities (42\%) or neighbourhoods surrounding the event (40\%). Majority $(67 \%)$ of the spectators were day visitors (not sleeping over in the host destination), with an average stay of three nights. The vast majority attended with friends (52\%), followed by family (19\%), friends and family (15\%), alone (4\%), as part of a cyclist support team (3.6\%) or other (including work colleagues, a sports club or educational group).

\section{Descriptive statistics and reliability of the scales}

Descriptive statistics and Cronbach's alpha levels of the scales are indicated in Table 4.

The two independent variables achieved satisfactory Cronbach's Alpha levels. The dependent variable 'Future Intention' also achieved a satisfactory Alpha level.

'Situational intention' at first achieved a low score of .608, but after the removal of two 
Table 4: Descriptive statistics and reliability of the scales

\begin{tabular}{|c|c|c|c|}
\hline Item & Mean & Std. Dev. & $\begin{array}{l}\text { Cronbach } \\
\text { Alpha }\end{array}$ \\
\hline \multicolumn{4}{|c|}{ Place attachment } \\
\hline Very attached to visiting this place specifically & 2.33 & .931 & \multirow{3}{*}{.730} \\
\hline Has a special connection to attending this cycling race & 2.69 & .996 & \\
\hline $\begin{array}{l}\text { Attending this particular event is more important than any } \\
\text { other }\end{array}$ & 2.41 & .970 & \\
\hline \multicolumn{4}{|l|}{$\begin{array}{ll} & \text { Subculture identification } \\
\end{array}$} \\
\hline Friends and family know me as a cycling supporter/fan & 2.60 & .991 & \multirow{3}{*}{.805} \\
\hline The sport of cycling describes me as a person & 2.11 & .903 & \\
\hline Strongly relate with other spectators and feel 'at home' & 2.69 & .893 & \\
\hline \multicolumn{4}{|l|}{$\begin{array}{ll}\text { Subjective norms } \\
\end{array}$} \\
\hline Seeing other spectators being environmentally responsible & $2.62 *$ & .546 & \multirow{3}{*}{.567} \\
\hline $\begin{array}{l}\text { Knowing that other spectators expect me to behave in an } \\
\text { environmentally responsible manner }\end{array}$ & 2.46 & .628 & \\
\hline Seeing the cyclists being environmentally responsible & 2.64 & .534 & \\
\hline \multicolumn{4}{|l|}{ Situational intention** } \\
\hline Stay in designated viewing areas & 3.64 & .682 & \multirow{10}{*}{.707} \\
\hline Read information signs to guide behaviour & 3.57 & .665 & \\
\hline Throw rubbish in the bins provided & $3.86 *$ & .460 & \\
\hline Make use of the ablution facilities & 3.69 & .648 & \\
\hline Pick up any visible litter & $3.06 *$ & .886 & \\
\hline Volunteer to pick up litter after the race & 2.44 & .933 & \\
\hline Report inappropriate behaviour of others & 2.64 & .924 & \\
\hline Refill water bottle with tap water & $2.73 *$ & 1.103 & \\
\hline Park vehicle only in designated areas & 3.63 & .740 & \\
\hline Take note of the surrounding natural environment & 3.50 & .701 & \\
\hline \multicolumn{4}{|l|}{$\begin{array}{ll} & \text { Future intention** } \\
\end{array}$} \\
\hline $\begin{array}{l}\text { Read the event's environmental rules and regulations } \\
\text { before attendance }\end{array}$ & 2.99 & .908 & \multirow{7}{*}{.755} \\
\hline $\begin{array}{l}\text { Willingness to make a financial contribution toward the } \\
\text { event's environmental initiatives }\end{array}$ & 2.54 & .847 & \\
\hline $\begin{array}{l}\text { Make use of public transport or car-pooling to reduce the } \\
\text { carbon footprint of the event }\end{array}$ & 2.70 & .964 & \\
\hline $\begin{array}{l}\text { Willingness to watch the race on television or over the } \\
\text { internet in order to reduce the environmental impact of the } \\
\text { event }\end{array}$ & $2.18 *$ & .956 & \\
\hline $\begin{array}{l}\text { Follow the event's environmental initiatives in the media } \\
\text { before deciding to return next year }\end{array}$ & 2.44 & .909 & \\
\hline $\begin{array}{l}\text { Sign a petition against the event if it becomes known that } \\
\text { the event has a negative impact on the environment where } \\
\text { it takes place }\end{array}$ & 2.62 & 1.015 & \\
\hline $\begin{array}{l}\text { Buy more products of the event sponsoring company } \\
\text { because they support this environmentally friendly event }\end{array}$ & 3.00 & .835 & \\
\hline
\end{tabular}

negatively worded items, the scale's reliability increased to a satisfactory level. Table 3

indicates the descriptive statistics and Alpha levels of the scales. The Cronbach's Alpa

for 'Subjective Norms' was low. The two reverse coded items were removed, but the 
scale still presented a low score. An exploratory factor analysis indicated that one item had a negative cross-loading and this problematic item was also removed. The remaining three items had a Cronbach's Alpha of 0.56 which is low but approaching 0.6 and can be considered (George \& Mallery, 2003). In the case of these three items the item inter-correlations were low, which reduces alpha. Furthermore items with low scale points (three in this case) may also produce an underestimate (Gliem \& Gliem, 2003; Takavol \& Dennick, 2011). It was therefore decided to retain this scale for further analysis.

Based on the item mean scores of each factor, spectators agreed mostly to the statement that they had a special connection to attending the specific cycling race $(M=2.69)$. No distinct differences were found between mountain bike versus road race spectators on any of the individual place attachment items or the overall scale composite score. Spectators agreed mostly to the statement that they could strongly relate with other spectators $(M=2.69)$. No distinct differences were found between mountain bike versus road race spectators on any of the subculture identification items or the overall scale composite score. Seeing cyclist being environmentally responsible would be the most encouraging aspect from a social norm viewpoint $(\mathrm{M}=2.64)$. Road race spectators were more encouraged by seeing other spectators behaving responsibly than mountain bike spectators $(\mathrm{F}=6.880$, $\mathrm{p}<.05)$. However, no significant difference was found based on the overall scale composite score.

The three most likely environmentally responsible activities while spectating would be throwing rubbish in bins $(\mathrm{M}=3.86)$, reading information signs to guide behaviour (M=3.57) and using ablution facilities $(\mathrm{M}=3.69)$. Least likely behaviour would be to volunteer to pick up litter after the race $(M=2.44)$. Mountain bike spectators 
displayed higher intentions than road race spectators to throw rubbish in bins ( $\mathrm{F}=4.068)$, volunteer to pick up litter after the race $(\mathrm{F}=3.590)$ and to refill water bottles with tap water $(\mathrm{F}=8.938)$. A significant difference was found based on the overall scale composite score with mountain bike spectators having higher overall levels of responsible situational intentions $(\mathrm{F}=7.885)$.

The three most likely activities in future would be buying more products of the event sponsoring company because they support this environmentally friendly event $(M=3.00)$, reading the event's environmental rules and regulations before attendance $(\mathrm{M}=2.99)$, and making use of public transport or car-pooling to reduce the carbon footprint of the event. Least likely activities were to avoid physical attendance in order to reduce the event's carbon footprint $(\mathrm{M}=2.18)$. Mountain bike spectators were however more likely to avoid physical attendance in order to reduce the event's carbon footprint $(\mathrm{F}=4.559)$. Again, a significant difference was found based on the overall scale composite score with mountain bike spectators having higher overall levels of responsible future intentions $(\mathrm{F}=14.634)$.

\section{Univariate analysis of covariance (ANCOVA)}

ANCOVA was performed to determine the interaction effects of the three factors, place attachment, subculture identification and subjective norms on the outcome variables, situational intention and future intention when distinguishing spectators based on event type. Where the previous analyses indicated differences in terms of specific dimensions of the factors as well as outcome variables based on item-level statistics, this analysis tests the relationships between the factors and the outcome variables based on the composite scores of the scales. 
Table 5 shows the results of the effects of the factors on behavioural intention when compared between road race and mountain bike spectators.

Table 5: Interaction effects of factors with behavioural intention based on event type

\begin{tabular}{|c|c|c|c|}
\hline \multicolumn{4}{|c|}{ Place attachment entered into the model } \\
\hline Source & $\mathbf{F}$ & Sig. & $\mathbf{R}^{2}$ \\
\hline Corrected Model & 22.432 & .000 & \multirow{4}{*}{.062} \\
\hline Intercept & 2603.243 & .000 & \\
\hline Place attachment & 38.082 & .000 & \\
\hline Event type & 7.383 & .007 & \\
\hline \multicolumn{4}{|c|}{ Subculture identification entered into the mode } \\
\hline Source & $\mathbf{F}$ & Sig. & $\mathbf{R}^{2}$ \\
\hline Corrected Model & 19.497 & .000 & \multirow{5}{*}{0.080} \\
\hline Intercept & 2163.959 & .000 & \\
\hline Place attachment & 4.530 & .034 & \\
\hline Subculture identification & 12.844 & .000 & \\
\hline Event type & 6.376 & .012 & \\
\hline \multicolumn{4}{|c|}{ Subjective norms entered into the model } \\
\hline Source & $\mathbf{F}$ & Sig. & $\mathbf{R}^{2}$ \\
\hline Corrected Model & 27.250 & .000 & \multirow{6}{*}{.139} \\
\hline Intercept & 486.782 & .000 & \\
\hline Place attachment & 2.836 & .093 & \\
\hline Subculture identification & 8.944 & .003 & \\
\hline Subjective norms & 46.573 & .000 & \\
\hline Event type & 5.000 & .026 & \\
\hline
\end{tabular}

Place attachment has a large significant relationship $(\mathrm{F}=38.082)$ with behavioural intention. The model only explains $6 \%$ of the variability in behavioural intentions. When subculture identification is added, place attachment still has a significant but smaller relationship with behavioural intention $(\mathrm{F}=4.530)$. Subculture identification has a larger significant relationship with behavioural intention $(\mathrm{F}=12.844)$. The explanatory power of the model increases slightly to $8 \%$. However, when the factor subjective norms is added the relationship between place attachment and behavioural intention becomes insignificant. Subculture identification still has a large significant relationship $(\mathrm{F}=8.944)$ while the factor subjective norms has a very large significant relationship $(\mathrm{F}=46.573)$. The predictive power of the model also increases to $14 \%$. Event type retains a significant relationship with behavioural intention throughout the process. 
Table 6 shows the results of the effects of the factors on future intention when compared between road race and mountain bike spectators.

Table 6: Interaction effects of factors with future intention based on event type

\begin{tabular}{|l|r|r|r|}
\hline \multicolumn{3}{|c|}{ Place attachment entered into the model } \\
\cline { 1 - 3 } Source & \multicolumn{1}{|c|}{ F } & \multicolumn{1}{c|}{ Sig. } & \multirow{2}{*}{$\mathbf{R}^{\mathbf{2}}$} \\
\hline Corrected Model & 31.620 & .000 & \\
\cline { 1 - 3 } Intercept & 661.870 & .000 & \multirow{2}{*}{.086} \\
\cline { 1 - 3 } Place attachment & 50.204 & .000 & \\
\cline { 1 - 3 } Event type & 14.144 & .000 & \\
\hline
\end{tabular}

\begin{tabular}{|l|r|r|r|}
\hline \multicolumn{3}{|c|}{ Subculture identification entered into the model } \\
\hline Source & \multicolumn{1}{|c|}{ F } & \multicolumn{1}{c|}{ Sig. } & \multicolumn{1}{|c|}{$\mathbf{R}^{2}$} \\
\hline Corrected Model & 27.295 & .000 & \\
\hline Intercept & 514.076 & .000 & \multirow{2}{*}{0.108} \\
\hline Place attachment & 5.866 & .016 & \multirow{2}{*}{0.00} \\
\cline { 1 - 2 } Subculture identification & 17.136 & .000 & \\
\cline { 1 - 3 } Event type & 12.509 & .000 & \\
\cline { 1 - 2 } & &
\end{tabular}

\begin{tabular}{|c|c|c|c|}
\hline \multicolumn{4}{|c|}{ Subjective norms entered into the model } \\
\hline Source & $\mathbf{F}$ & Sig. & $\mathbf{R}^{2}$ \\
\hline Corrected Model & 23.561 & .000 & \multirow{6}{*}{.123} \\
\hline Intercept & 108.473 & .000 & \\
\hline Place attachment & 4.786 & .029 & \\
\hline Subculture identification & 14.506 & .000 & \\
\hline Subjective norms & 11.130 & .001 & \\
\hline Event type & 11.413 & .001 & \\
\hline
\end{tabular}

Place attachment has a large significant relationship $(\mathrm{F}=50.204)$ with future intention.

The model only explains $9 \%$ of the variability in future intentions. When subculture identification is added, place attachment still has a significant but much smaller relationship with future intention $(\mathrm{F}=5.866)$. Subculture identification has a larger significant relationship with future intention $(\mathrm{F}=17.136)$. The explanatory power of the model increases slightly to $11 \%$. When the factor subjective norms is added the relationship between place attachment and future intention remains significant $(\mathrm{F}=4.786)$. Subculture identification still has a large significant relationship $(\mathrm{F}=14.506)$ 
while subjective norms has a large significant relationship $(\mathrm{F}=11.130)$. The predictive power of the model also increases to $12 \%$.

\section{Conclusion and recommendations}

Descriptive data analysis indicated that there were no significant differences in the levels of place attachment, subculture identification or subjective norms between road race and mountain bike spectators. However, for both situational and future intentions, mountain bike spectators displayed higher levels of responsible behavioural intention.

The ANCOVA analysis indicated changes in the significance and effect size of the physical context (place attachment and event type) with the introduction of the social context. In the case of situational intention, both place attachment and event type initially had significant effects on intention. However, after the inclusion of subculture identification their effect sizes decreased and after the inclusion of subjective norms, place attachment did not have a significant relationship with behavioural intentions and effect of the physical setting decreased further. It could be concluded that within the setting (while spectating) the social context (the behaviour and expectations of fellow spectators) had more potential than the physical setting or the attachment thereto, to influence behavioural intentions. This finding is significant as it proves the relative importance of a person's identification with the social context at a sports event to influence behaviour; supporting McCullough and Kellison's (2016) statement that when fans attend a sport event and "engage in the spectacle around the event" their social identity (as a fan) may dominate other identities such as an environmental identity. It corresponds with previous research suggesting that communication strategies at an event should be built around subjective norms (Casper et al., 2014; McCullough \& Cunningham, 2011), making use of appropriate 'message framing' (Cheng, Woon \& 
Lynes, 2011) to encourage pro-environmental behaviour. Based on the descriptive data analysis, using cyclists as 'environmental ambassadors' could be especially relevant; corresponding with research indicating the positive influence of sport teams to encourage pro-environmental behaviour among fans (Inoue et al., 2012).

In terms of future intention, all three factors retained significant levels of interaction indicating that both the social and physical contexts could potentially influence responsible decision-making in the future. Once outside of the setting and direct contact with other spectators, individuals may be more inclined to turn to their sense of attachment to the place or event along with what individuals expect other spectators would be doing. By showing the varied influence of the social context on behavioural intentions, this study contradicts findings by Dolnicar and Grün (2009) arguing that tourists' environmental behaviour is not context/environment dependent but that individuals display similar behaviour at home and in holiday settings. In terms of the physical setting, a strong attachment to the place or event may prove beneficial as these spectators appreciate the place and are more prone to support event organisers' environmental management initiatives through using public transport to the event and reading the rules and regulations before actual attendance. Communicating to spectators based on place attachment and referral to the quality of the setting which they may plan to attend again in future may encourage them to convert some of their responsible behaviour of the past into future behaviour especially with reference to the same event (Wu et al., 2013). It is important to note some of the future intentions measured are not necessarily all favourable for event organisers and include following an event's environmental initiatives in the media before deciding to return or even not attending if an event becomes known to be unsustainable (corresponding with studies by Laing \& Frost, 2010 and Puczkó \& Smith, 2012). 
Limitations of this study include limiting the spectator groupings only to event type, while other variables could also add to explaining differences (for example place of origin, travel group and demographics). Research could also explore the three factors as drivers of environmentally responsible behaviour amongst sport spectators in different sport settings and sport codes. This can be linked to research exploring the extent to which different sporting codes are perceived as being 'green' by attendees. The finding that mountain bike spectators showed higher levels of responsible intentions, could be explored further to determine whether the sport itself is associated with environmentally responsible behaviour or whether it is the physical (natural) setting that encourages these intentions. If the former is the case, there would be the potential for these values to be adopted and internalised by individuals who strongly associate with the subculture and use it to express this aspect of their self-concept (after Hirt \& Clarkson, 2011; McCullough \& Kellison, 2016; Scammon et al., 2011; Shipway \& Kirkup, 2011). If the latter is true, the influence of the natural setting on behaviour should be explored through factors not tested in this research such as environmental awareness. The fact that behavioural intentions and not actual behaviour were measured is a further limitation. Future research should focus on actual pro-environmental behaviour in addition to intentions.

\section{References}

Ajzen, I., \& Fishbein, M. 1980. Understanding Attitudes and Predicting Social Behavior. Englewood Cliffs, NJ: Prentice-Hall.

Ajzen, I. 1991. The theory of planned behavior. Organizational Behavior and Human Decision Processes, 50(2):179-211.

Ajzen, I. 2011. The theory of planned behaviour: reactions and reflections. Psychology \& Health, 26(9):1113-1127. 
Aldred, R. 2010. 'On the outside': constructing cycling citizenship. Social \& Cultural Geography, 11(1):35-52.

Andorfer, V.A. \& Liebe, U. 2013. Consumer behavior in moral markets. On the relevance of identity, justice beliefs, social norms, status and trust in ethical consumption. European Sociological Review, 29(6):1251-1265.

Baldwin, R.M. 2010. Can (A Football) Community Tackle Climate Change? A Case Study Analysis of Ipswich Town Football Club's Campaign to Encourage ProEnvironmental Behavioural Change Amongst Its Fans. CSERGE Working Paper EDM 10-05, School of Environmental Sciences, University of East Anglia, Norwich. [Online] Available from:

http://prototype2010.cserge.webapp3.uea.ac.uk/sites/default/files/edm_2010_05. pdf [Downloaded: 2012-03-13].

Bamberg, S. \& Möser, G. 2007. Twenty years after Hines, Hungerford, and Tomera: a new meta-analysis of psycho-social determinants of pro-environmental behaviour. Journal of Environmental Psychology, 27:14-25.

Barry, H. 2014. Cycling is the New Golf. [Online] Available from: http://www.moneyweb.co.za/archive/cycling-is-the-new-golf/ [Accessed: 201605-02].

Belk, R.W. 1975. Situational variables and consumer behaviour. Journal of Consumer Research, 2(3):157-164.

Bicchieri, C. 2006. The Grammar of Society. New York: Cambridge University Press.

Biel, A. \& Thogersen, J. 2007. Activation of social norms in social dilemmas: a review of the evidence and reflections on the implications for environmental behaviour. Journal of Economic Psychology, 28:93-112.

Blake, J. 1999. Overcoming the 'value-action' gap in environmental policy: tensions between national policy and local experience. Local Environment, 4(3): 257278.

Bonnes, M. \& Bonaiuto, M. 2002. Environmental psychology: from spatial-physical environment to sustainable development. In Bechtel, R.B. and Churchman, A. (Eds.) Handbook of Environmental Psychology (pp. 28-54). John Wiley \& Sons: New York.

Brymer, E. \& Gray, T. 2010. Developing an intimate 'relationship' with nature through extreme sports participation. Leisure/Liosir, 34(4):361-374. 
Brymer, E., Downey, G. \& Gray, T. 2009. Extreme sports as a precursor to environmental sustainability. Journal of Sport and Tourism, 14(2-3):193-204.

Cameron, L.D. 2002 Promoting positive environmental behaviours through community interventions: a case study of waste minimisation. Environment Waikato Technical Report No. 13. Hamilton, Australia: Waikato Regional Council. [Online] Available from: http://www.waikatoregion.govt.nz/PageFiles/2493/ tr02-13.pdf [Downloaded: 2013-08-19].

Casper, J.M. \& Pfahl, M.E. 2012. Environmental behavior frameworks of sport and recreation undergraduate students. Sport Management Education Journal, 6:820.

Casper, J.M., Pfahl, M.E. \& McCullough, B. 2014. Intercollegiate sport and the environment: examining fan engagement based on athletic department sustainability efforts. Journal of Issues in Intercollegiate Athletics, 7:65-91.

Cheng, T., Woon, D.K. \& Lynes, J.K. 2011. The use of message framing in the promotion of environmentally sustainable behaviors. Social Marketing Quarterly, 17(2):48-62.

Cialdini, R.B., \& Trost, M.R. 1998. Social influence: social norms, conformity, and compliance. In: Gilbert, D.T., Fiske, S.T. \& Lindzey, G. (Eds.) The Handbook of Social Psychology, $4^{\text {th }}$ Edition, Vol. 2, pp.151-192. New York: McGraw-Hill.

Collins, A., Roberts, A. \& Munday, M. 2012. The Environmental Impacts of Major Cycling Events: Reflections on the UK Stages of the Tour de France. Cardiff University, Cardif. [Online] Available from: http://orca.cf.ac.uk/53325/1/Tourde-France.pdf [Accessed: 2016-05-02].

Cornelissen, G., Pandalaere, M., Warlop, L. \& Dewitte, S. 2008. Positive cueing: promoting sustainable consumer behaviour by cueing common environmental behaviours as environmental. International Journal of Research in Marketing, 25:46-55.

Cupples, J. \& Ridley, E. 2008. Towards a heterogeneous environmental responsibility: sustainability and cycling fundamentalism. Area, 40(2):254-264.

Dolnicar, S. \& Grün, B. 2009. Environmentally friendly behavior: can heterogeneity among individuals and contexts/environments be harvested for improved sustainable management? Environment and Behavior, 41(5):693-714. 
Du Toit, N. 2013. Did the African cycling dream impact on the cycling trade? Sports Trader - for the Sport, Outdoor \& Leisure Industries, October/November.

[Online] Available from: http://www.sportstrader.co.za/pages/issue\%20articles/ 2013OctNov/Cyclingimpactsonsales.php [Accessed: 2016-05-02].

Elster J. 1999. Strong Feelings. Cambridge, MA: MIT Press.

Field, A.P. 2013. Discovering Statistics Using SPSS: And Sex and Drugs and Rock 'n Roll. $4^{\text {th }}$ Edition. London: Sage.

Filo, K., Funk, D.C. \& O’Brien, D. 2008. The Influence of Social Responsibility on Sport Tourists. Paper presented at the CAUTHE 2008 Conference. [Online] Available from: http://132.234.243.22/conference/cauthe2008/refereedpapers/RP014.pdf [Downloaded: 2012-03-13].

Fink, A. \& Smith, D.J. 2012. Norms in sports contests: the Tour de France. Journal of Sport Management, 26:43-52.

Funk, D.C. 2008. Consumer Behaviour in Sport and Events: Marketing Action. Oxford, UK: Elsevier.

Gliem, J.A. \& Gliem, R.R. 2003. Calculating, Interpreting, and Reporting Cronbach's Alpha Reliability Coefficient for Likert-Type Scales. Midwest Research to Practice Conference in Adult, Continuing, and Community Education, The Ohio State University, Columbus, Ohio, October 8-10. [Online] Available from: http://www.ssnpstudents.com/wp/wp-content/uploads/2015/02/Gliem-Gliem.pdf [Accessed: 2016-05-01].

George, D. \& Mallery, P. 2003. SPSS for Windows step by step: A simple guide and reference. 11.0 update (4th ed.). Boston: Allyn \& Bacon.

Goldstein, N.J., Cialdini, R.B. \& Griskevicius, V. 2008. A room with a viewpoints: using social norms to motivate environmental conservation in hotels. Journal of Consumer Research, 35(3):472-482.

Green, B.C. 2001. Leveraging subculture and identity to promote sport events. Sport Management Review, 4, 1-19.

Green, B.C. \& Chalip, L. 1998. Sport tourism as the celebration of subculture. Annals of Tourism Research, 25(2), 275-291.

Greening the WSSD. (2003). Responsible tourism handbook - a guide to good practice for tourism operators. Not known: Greening the WSSD [Online]. Retrieved April 16, 2012, from https://www. 
globalnature.org/bausteine.net/f/5801/Tourismhandbook.pdf?fd=2GSA. 2006.

Mainstreaming the Environment in Major Sports Events. Report of the Global Forum for Sport and Environment, Lausanne, Switzerland, 30 November - 1

December. [Online] Available from: http://www.unep.org/Spanish/ Sport_env/Activities/gf2006.asp [Accessed: 2012-02-05].

Günther, H. 2009. The environmental psychology of research. Journal of Environmental Psychology, 29:358-365.

Halpenny, E.A. 2010. Pro-environmental behaviours and park visitors: the effect of place attachment. Journal of Environmental Psychology, 30:409-421.

Hardisty, C. 2014. Boom time for cycling. Sports Trader - for the Sport, Outdoor \& Leisure Industries, November. [Online] Available from: http://www.sportstrader.co.za/pages/Issue\%20articles/2014November/boomtime forcycling.php [Accessed: 2016-05-02].

Hedlund, D. 2012. An empirical model of sport fan consumption communities.Workshop: ESMQ 2013 Special Issue: Value co-creation in sport management. 18 - 21 September, Aalborg, Denmark. Available from www.easm2012.com

Hinch, T. \& Higham, J. 2011. Sport Tourism Development, $2^{\text {nd }}$ Edition. Bristol: Channel View Publications.

Hirt, E.R. \& Clarkson, J.J. 2011. The psychology of fandom: understanding the etiology, motives and implications of fanship. In: Kahle, L.R. \& Close, A.G. (Eds.) Consumer Behavior Knowledge for Effective Sports and Event Marketing, pp.59-85. New York: Routledge.

Iconaru, C. 2012. Modeling the impact of normative beliefs in the context of online buying: direct and moderation effects. The Romanian Economic Journal, 44:243-262.

Inoue, Y., Kent, A. \& Smart, D.L. 2012. Sport teams as promoters of pro-environmental behavior: an empirical study. Journal of Sport Management, 26(5):417-432.

Jagemann, H. 2003. Sports and the Environment: Ways Towards Achieving the Sustainable Development of Sport. Paper presented at the $4^{\text {th }}$ Pierre de Coubertin School Forum Arenzano (MUVITA), 22 September. [Online] Available from: http://www.thesportjournal.org [Accessed: 2012-04-24]. 
Kachel, U. \& Jennings, G. 2010. Exploring tourists' environmental learning, values and travel experiences in relation to climate change: a postmodern constructivist research agenda. Tourism and Hospitality Research, 10:130-140.

Kang, K. J. \& Stotlar, D. (2011). An investigation of factors influencing decision making for participation in the Olympic partners sponsorship: A case study of Samsung. International Journal of Applied Sports Sciences, 23(1), 225-250.

Kellison, T.B. \& Kim, Y.K. 2014. Marketing pro-environmental venues in professional sport: planting seeds of change among existing and prospective consumers. Journal of Sport Management, 28:34-48.

Keyton, J. 2011. Communication Research: Asking Questions, Finding Answers. $3^{\text {rd }}$ Edition. New York: McGraw-Hill.

King, J., Kahle, L.R. \& Close, A.G. 2011. Introduction: the study of sports and events consumer behavior. In: Kahle, L.R. \& Close, A.G. (Eds.) Consumer Behavior Knowledge for Effective Sports and Event Marketing, pp.1 - 28. New York: Routledge.

Klöckner, C.A. \& Blöbaum, A. 2011. A comprehensive action determination model: toward a broader understanding of ecological behaviour using the example of travel mode choice. Journal of Environmental Psychology, 30:574-586.

Kollmuss, A. \& Agyeman, J. 2002. Mind the gap: why do people act environmentally and what are the barriers to pro-environmental behavior? Environmental Education Research, 8(3):239:259.

Krosnick, J.A. 1999. Survey research. Annual Review Psychology, 50:537-567.

Kruger, M. \& Saayman, M. 2014. How do mountain bikers and road cyclists differ? South African Journal of Research in Sport, Physical Education and Recreation, 36(2):137-152.

Kulczycki, C. \& Halpenny, E.A. 2014. Sport cycling tourists' setting preferences, appraisals and attachments. Journal of Sport and Tourism, 19(2):169-197.

Kyle, G., Graefe, A.R.,Manning, R., \& Bacon, J. 2003. An examination of the relationship between leisure activity involvement and place attachment among hikers along the Appalachian Trail. Journal of Leisure Research, 35(3):249-273.

Kyle, G., Graefe, A., Manning, R. \& Bacon, J. 2004. Effects of place attachment on users' perceptions of social and environmental conditions in a natural setting. Journal of Environmental Psychology, 24:213-225. 
Laing, J. \& Frost, W. 2010. How green was my festival: exploring challenges and opportunities associated with staging green events. International Journal of Hospitality Management, 29: 261-267.

Lamont, M. 2009. Reinventing the wheel: a definitional discussion of bicycle tourism. Journal of Sport \& Tourism, 14(1):5-23.

Laroche, M., Tomiuk, M., Bergeron, J. \& Barbaro-Forleo, G. 2002. Cultural differences in environmental knowledge, attitudes, and behaviours of Canadian consumers. Canadian Journal of Administrative Sciences, 19(3):267-283.

Lee, K. 2011. The role of media exposure, social exposure and biospheric value orientation in the environmental attitude-intention-behavior model in adolescents. Journal of Environmental Psychology, 31:301-308.

Lee, W.H. \& Moscardo, G. 2005. Understanding the impact of ecotourism resort experiences on tourists' environmental attitudes and behavioural intentions. Journal of Sustainable Tourism, 13(6):546-565.

López-Mosquera, N. \& Sánchez, M. 2012. Theory of planned behaviour and the valuebelief-norm theory explaining willingness to pay for a suburban park. Journal of Environmental Management, 113:251-262.

Luo, Y. \& Deng, J. 2008. The new environmental paradigm and nature-based tourism motivation. Journal of Travel Research, 46(4):392-402.

Mansfield, L. \& Wheaton, B. 2011. Leisure and the politics of the environment. Leisure Studies, 30(4):383-386.

McCullough, B.P. 2013. Identifying the influences on sport spectator recycling behaviours using the theory of planned behaviour. International Journal of Sport Management and Marketing, 14:146-168.

McCullough, B.P. \& Cunningham, G.B.C. 2011. Recycling intentions among youth baseball spectators. International Journal of Sport Management and Marketing, 10(1/2), 104-120.

McCullough, B.P. \& Kellison, T.B. 2016. Go green for the home team: sense of place and environmental sustainability in sport. Journal of Sustainability Education, 11.

Mehmetoglu, M. 2010. Accurately identifying and comparing sustainable tourists, nature-based tourists and ecotourists on the basis of their environmental 
concerns. International Journal of Hospitality and Tourism Administration, 11(2):171-199.

Miao, L. \& Wei, W. 2013. Consumers' pro-environmental behavior and the underlying motivations: a comparison between household and hotel settings. International Journal of Hospitality Management, 32:102-112.

Milfont, T.L., Duckitt, J. \& Wagner, C. 2010. A cross-cultural test of the ValueAttitude-Behavior Hierarchy. Journal of Applied Social Psychology, 40(11):2791-2813.

Montaño, D.E. \& Kasprzyk, D. 2008. Theory of Reasoned Action, Theory of Planned Behaviour, and the Integrated Behavioral Model. In: Glanz, K., Rimer, B.K. \& Viswanath, K. (Eds.) Health Behavior and Health Education - Theory, Research and Practice, pp.67-92. San Francisco: Jossey-Bass.

Moscardo, G. 2009. Tourism and quality of life: towards a more critical approach. Tourism and Hospitality Research, 9(2):159-170.

Nguyen, S., Iacono, V. \& Stratmann, W. 2011. To be "Green" or Not to be "Green": The Perspectives of Sport Consumer on the Relationship Between Sport and the Environment. In NASSM 2011: Book of Abstracts, NASSM, London, Canada. [Online] Available from: http://hdl.handle.net/10536/DRO/DU:30036823 [Downloaded: 2012-03-13].

Nigbur, D., Lyons, E. \& Uzzell, D. 2010. Attitudes, norms, identity and environmental behaviour: using an expanded theory of planned behaviour to predict participation in a kerbside recycling programme. British Journal of Social Psychology, 49:259-284.

Pearce, P.L. 2005. Tourist Behaviour - Themes and Conceptual Schemes. Clevedon: Channel View Publications.

Pearce, P.L. 2011. Tourist Behaviour and the Contemporary World. Ontario, Canada: Channel View Publications.

Pfahl, M.E. 2010. Strategic issues associated with the development of internal sustainability teams in sport and recreation organizations: a framework for action and sustainable environmental performance. International Journal of Sport Management, Recreation and Tourism, 6:37-61. 
Pucher, J., Buehler, R. \& Seinen, M. 2011. Bicycling renaissance in North America? An update and re-appraisal of cycling trends and policies. Transportation Research Part A, 45:451-475.

Pucher, J., Garrard, J. \& Greaves, S. 2011. Cycling down under: a comparative analysis of bicycling trends and policies in Sydney and Melbourne. Journal of Transport Geography, 19:332-345.

Puczkó, L. \& Smith, M. 2012. An analysis of tourism QOL domains from the demand side. In: Uysal, M., Perdue, R.R. \& Sirgy, M.J. (Eds.) Handbook of Tourism and Qualify-of-Llife Research - Enhancing the Lives of Tourists and Residents of Host Communities, pp.263-277. New York: Springer.

Ramkissoon, H., Smith, L.D.G. \& Weiler, B. 2013. Relationships between place attachment, place satisfaction and pro-environmental behaviour in an Australian national park. Journal of Sustainable Tourism, 21(3):434-457.

Ray, S.J. 2009. Risking bodies in the wild: the 'corporeal unconscious' of American adventure culture. Journal of Sport and Social Issues, 33(3):257-284.

Responsible Traveller Magazine. (2014). Responsible traveller - Be the difference. [Online] Retrieved April 10, 2014, from http://www.responsibletraveller.co.za /responsibletraveller1.co.za

Ritchie, B.W., Tkaczynski, A. \& Faulks, P. 2010. Understanding the Motivation and Travel Behavior of Cycle Tourists Using Involvement Profiles, Journal of Travel \& Tourism Marketing, 27(4):409-425.

Sahler, G. 2007. Green Champions in Sport and Environment. Berlin: Federal Ministry for the Environment, Nature Conservation and Nuclear Safety. [Online] Available from: http://www.unep.org/sport_env/FinalGreenChampions_Guide_ 070928.pdf [Downloaded: 2010-08-10].

Salome, L.R., Van Bottenburg, M. \& Van den Heuvel, M. 2013. We are as green as possible: environmental responsibility in commercial artificial settings for lifestyle sports. Leisure Studies, 32(2):173-190.

Saunders, M., Lewis, P. \& Thornhill, A. 2007. Research Methods for Business Students. 4th Edition. Essex, UK: Prentice Hall.

Scammon, D.L., Fuller, D.A., Karniouchina, E.V. \& Masters, T. 2011. Sport-related subculture as a useful basis of market segmentation. In: Kahle, L.R. \& Close, 
A.G. (Eds.) Consumer Behavior Knowledge for Effective Sports and Event Marketing, pp.103 - 143. New York: Routledge.

Schmidt, C.W. 2006. Putting the earth in play: environmental awareness and sports. Environ Health Perspect, 114(5):A286-A295. [Online] Available from: http://www.ncbi.nlm.nih.gov/pmc/articles/PMC1459948/ [Accessed: 2012-0413].

Schwartz, S.H. 1977. Normative influences on altruism. In: Berkowitz, I. (Ed.) Advances in Experimental Social Psychology, pp.221-279. New York: Academic Press.

Sheth, J.N., Sethia, N.K. \& Srinivas, S. 2011. Mindful consumption: a customer-centric approach to sustainability. Journal of the Academy of Marketing Science, 39:2139.

Shipway, R. \& Kirkup, N. 2011. Understanding sport tourism experiences: exploring the participant-spectator nexus. In: Sharpley, R. \& Stone, P.R. (Eds.) Tourist Experience - Contemporary Perspectives, pp.127-140. London: Routledge.

Snelgrove, R., Taks, M., Chalip, L. \& Green, C. 2008. How visitors and locals at a sport event differ in motives and identity. Journal of Sport \& Tourism, 13(3):165-180.

Snelgrove, R., \& Wood, L. 2010. Attracting and leveraging visitors at a charity cycling event. Journal of Sport \& Tourism, 15(4):269-285.

Snider, A., Hill, J., Luo, S., Buerger, B. \& Herstine, J. 2011. Implications for place attachment in coastal reserve management. Ocean and Coastal Management, 54:612-620.

Sotiriadou, P. \& Hill, B. 2015. Raising environmental responsibility and sustainability for sport events: a systematic review. International Journal of Event Management Research, 10(1):1-11.

Stanford, D. 2008. 'Exceptional Visitors': dimensions of tourist responsibility in the context of New Zealand. Journal of Sustainable Tourism, 16(3):258-275.

Steg, L., Bolderdijk, J.W., Keizer, K. \& Perlaviciute, G. 2014. An integrated framework for encouraging pro-environmental behaviour: the role of values, situational factors and goals. Journal of Environmental Psychology, 38:104-115.

Stern, P.C. 2000. Toward a coherent theory of environmentally significant behavior. Journal of Social Issues, 56(3):407-424. 
Szymanski, S. 2003. The economic design of sporting contests. Journal of Economic Literature, 41:1137-1187.

Takavol, M. \& Dennick, R. 2011. Making Sense of Cronbach's alpha. International Journal of Medical Education, 2:53-55.

Tang, L. 2014. The application of social psychology theories and concepts in hospitality and tourism studies: a review and research agenda. International Journal of Hospitality Management, 36:188-196.

Thompson, J., Davidson, J. \& Hutson, G. 2008. A case study on environmental perspectives of boulderers and access issues at the Niagara Glen Nature Reserve. Australian Journal of Outdoor Education, 12(2):XX-XY.

Trendafilova, S. 2011. Sport subcultures and their potential for addressing environmental problems: the illustrative case of disc golf. The Cyber Journal of Applied Leisure and Recreation Research, 13(1):1-14. [Online] Available from: http://larnet.org/2011-03.pdf [Downloaded: 2012-03-13].

Weaver, D. 2012. Organic, incremental and induced paths to sustainable mass tourism convergence. Tourism Management, 33:1030-1037.

Weed, M. \& Bull, C. 2004. Sports Tourism: Participants, Policy and Providers. Oxford: Elsevier Butterworth-Heinemann.

Wheaton, B. 2007. Identity, politics and the beach: environmental activism in surfers against sewage. Leisure Studies, 26(3):279-302.

Winkel, G., Seagert, S. and Evans, G.W. 2009. An ecological perspective on theory, methods and analysis in environmental psychology: advances and challenges. Journal of Environmental Psychology, 29:318-328.

Wu, J., Huang, D., Liu, J. \& Law, R. 2013. Which factors help visitors convert their short-term pro-environmental intentions to long-term behaviors? International Journal of Tourism Sciences, 13(2):33-56.

Wynveen, C.J., Kyle, G.T. \& Sutton, S.G. 2012. Natural area visitors' place meaning and place attachment ascribed to a marine setting. Journal of Environmental Psychology, 32:287-296.

Yang, C.C., Yang, K.J. \& Peng, S.Y. 2011. Exploration strategies and key activities for the system of environmental management. Total Quality Management and Business Excellence, 22(11):1179-1194. 